\title{
Comparative Analyses of the Return on Investment of 2013 and 2015 Mineral Policy Reforms in Burkina Faso
}

\author{
"AGYEI, G; OPAFUNSO, ZO; YAMEOGO, KW \\ "Department of Mining Engineering, University of Mines \& Technology, Tarkwa, Ghana \\ *Corresponding Authore-mail: gagyei@umat.edu.gh \\ zoopafunso@umat.edu.gh; ykevinwilliams@yahoo.fr
}

\begin{abstract}
This paper evaluates the effects of the changes in Burkina Faso's mineral policies of 2013 and 2015 and their economic attractiveness using the Natougou Project as case study. Cash flow analyses shows a higher NPV of US $\$ 93,817,833.84$ and an IRR of $44.67 \%$ under the 2015 Mining Code. Sensitivity analysis shows the project was less sensitive under the 2003 Mining Code as it takes a $18.25 \%$ decrease in the revenue for the project to break even as against 13.04\% under the 2015 Mining Code. The project was insensitive to changes in operating cost and capital cost under the 2003 Mining Code but will not be viable if the capital cost and operating cost increase beyond 30\% and 32.75\% respectively for the 2015 Mining Code. An amount of US \$ 321,488,366.61 will accrue to the government for 2015 Mining Code as against US\$245,442,053.07 for the 2003 Mining Code.
\end{abstract}

\section{DOI: https://dx.doi.org/10.4314/jasem.v22i8.15}

Copyright: Copyright $\odot 2018$ Agyei et al. This is an open access article distributed under the Creative Commons Attribution License (CCL), which permits unrestricted use, distribution, and reproduction in any medium, provided the original work is properly cited.

Dates: Received: 02 June 2018; Revised: 22 July: 2018; Accepted: 26 August 2018

Keywords: Mining Code, investment, physical policies, dividends, sensitivity analysis, government and project.

Burkina Faso, a West African nation, has witnessed an exponential mining boom in recent years. The growth in mine production is as a results of Foreign Direct Investment (FDI) propitiated by the favorable business climate created by progressive tax regimes and modern mining fiscal policies. Currently the country has positioned itself as the fourth largest producer of gold after South Africa, Ghana and Mali. The export of gold has surpassed traditional exports like livestock and agricultural products (Dabire, 2015). Burkina Faso exports around 40 metric tons of gold annually. Several greenfield gold mining projects have sprang up. Natougou Gold Project is one of the promising enterprises.

Location of Natougou Gold Deposit: The Natougou Project site fig. 1 is situated at about 320 kilometres Southwest of Ouagadougou, the capital city of the country. The Natougou deposit area is connected to the rest of the immediate town by well paved roads linking Kantchari through Fada N'Gourma and Diapaga, The geographical coordinates are $12^{\circ} 37^{\prime} 0^{\prime \prime}$ North and $1^{\circ} 41^{\prime} 0$ " East.

Geology of Natougou Gold Deposit: The West African Birimian Greenstone belt is predominantly composed of lower Protozoic age and sedimentary units with intrusions of related plutonic rock formations. The Natougou deposit is found within this geological formation, specifically in the southern rims of the Diapaga Greenstone belt in the Eastern Region of Burkina Faso. The concessions reveal greenstone formations similar to the Tarkwaian gold belts of Ghana and include extensions of Natougou Rock Structure. The gold deposit is found in the Natougou petrography, an exposed flat laying lithology in the South Eastern edge of the country. The structure is hosted in amphibole greenstones which form an open dome dipping to North West. It is a massive deposit composed of high grade flat laying quartz sulphide lodes

The mineralogy of the deposit occurs within a flat laying shear zone that possess a subtle anticlinal geometry and contains mafic to transitional volcanic/ intrusive beddings. The gold minerals are hosted in silicified shear zone and large portions occur as free milling ores. Sulphide encapsulated refractory ores like pyrrhotite, pirite and minor asrsenopirite and chacopirites are disseminated in the strong shearing, sheeted and deformed quartz veins and silified zones. However, coarse free milling gold is contained within the mineralised zones as well.

The objective of this study was to assess the effects of changes in fiscal mineral policies on the viability of mineral projects in Burkina Faso. This was achieved through the assessment and evaluation of the various 
fiscal policies governing mining royalties, taxes, and allowances within two major mining policy reforms. The data generated were then used to carry out cash flow and sensitivity analysis using the Natougou mining project as a case study.

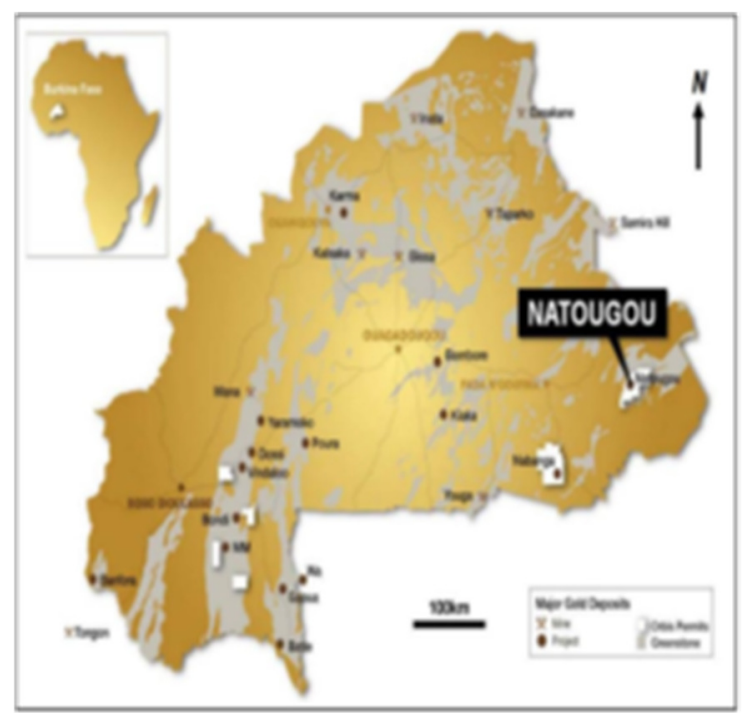

Fig 1: The Location of Natougou Mining Project

General Overview Mineral Policy Reforms in Burkina Faso: Proponents of the current mining legislation argue it aims to strike a balance between exploitation of natural resources and the promotion of economic and social development of the country. The scope of the Mining Code encompasses prospection, exploration, exploitation, processing and marketing of the mineral products excluding water and fossil fuels. The 2015 Mining Reforms reaffirm the following: (1) The mineral deposits contained in the soil and subsoil are vested in the state in trust of the people; (2) The state shall ensure the development of the resources through private initiatives and Foreign Direct Investment; (3) Any individual or a legal entity from Burkina Faso or a foreign national may carry out a mining activity under the Mining Code. However foreign entities are not permitted to extract minerals directly. Foreign companies need to incorporate or set up a legal entity regulated entirely by the laws of Burkina Faso; and (4) A title holder who is not a resident may be allowed to operate provided a national agent registered by the Administrator of Mines is presented. The appointed agent must have a strong knowledge of the mining codes of the country and follow registration procedures spelt out by the Administration of Mines (Anon, 2015; Wafwana, 2013).

Taxation has variable effects on various margins of resource development (Smith, 2013). Several mineral taxation reforms have been introduced. The Code has affixed taxes for certain mining activities with their corresponding tax exemptions and incentives for different stages of mine development to promote the competitiveness of Burkina Faso.

Article 93 of the Mining Code 2015 limits the stabilisation clause to twenty years and the mining convention is signed only during the exploitation unless renewals are granted. Holders of permits are required to payment of fixed charges proportional to the surface area and the mining royalties ( $A d$ Valorem). Holders of mining titles are also required to pay annual fees dependent on the size of the surface area and the expected duration of the mine (Anon, 2015; Calame 2015).

The current rates for mineral royalties are as follows: $8 \%$ for uranium, $7 \%$ for diamonds and gemstones, between 3\% and 5\% for gold and precious metals depending on the price in the metal market. During the development stage mining companies can enjoy some tax benefits like exemption of Value Added Tax (VAT) on certain imported goods and services. These VAT exceptions can be extended to a maximum of two years provided the project targets reaches at least 50\% of completion. During the development stage, tax exemptions are extended to procurement of raw materials, fuels, lubricants, vehicles and spare parts. The exemptions include community solidarity charges and other community development funding related charges.

The moratorium on taxes can last for a maximum of three years and ends on the first day of the commencement of production. When mining reaches the exploitation stage the companies are required to pay tax on industrial and commercial profits and taxes on tangible assets which have been reduced by $10 \%$. The reduction has been taken care of by the New Mining Code (2015) fixing the tax to paid at 27\%. The 2013 Mining Code provided for significant tax incentives during exploitation stage such as exemption of seven years patent tax, employer and apprentice tax and registration fee for certain corporate acts (Anon, 2009). The 2015 Mining Code changes the old tax and customs regime. The review of 2015 has introduced a mandatory Corporate Social Responsibility clause in form of taxation.

Taxation is an attribute of sovereignty and a conduit for national development, however it has strengths and limitations for the development of sustainable mining. A community development fund which takes $1 \%$ of the turnover after exploitation of minerals is a new feature of the 2015 Mine Code and this particular tax 
underscores the aspirations of host communities to reap the benefits of mineral resources. The state shall in turn transfer $25 \%$ of the royalties to the Community Development Fund. However, the modality for the disbursement of the fund is not well defined. Tilton (2004) questions the real social impact of such funds in the resource-rich communities because the impact of such revenues in the host communities is sometimes debatable. For example, mining companies in Ghana have voluntarily pledged to contribute one dollar per every ounce of gold to the various Community Development Funds in the communities. However, in most instances these resources have not yielded the expected results due to misapplication and misappropriation of these resources by corrupt traditional leaders, local government officials and community leaders of the mining districts. This has contributed to avoidable strained relations between belligerent communities and the mining companies in Ghana. Giving the Burkinabe mineral endowments, the success of the Community Development Tax has the potential of spiraling harmful tax competition on the continent.

\section{MATERIALS AND METHODS}

When a company is confronted with several investment alternatives, it becomes necessary to evaluate the economic attractiveness of each alternative and accept or reject it. Any evaluation criterion should provide a company's management with a means of distinguishing between acceptable projects in a consistent manner. In addition, it is desirable for the evaluation criterion to provide a ranking of the acceptable investment alternatives in order of their desirability to assist in selecting the alternative with the best economic potential. Any investment decision method must respect these two basic principle (Barra, 2015; Laporte and Quatrebarbes, 2015). Bigger benefits are preferable to smaller benefits; and early benefits are preferable to later benefits. There are several criteria for evaluating the economic attractiveness of an investment proposal with the most widely used in the mining industry being Net Present Value (NPV); Internal Rate of Return (IRR); and Discounted Pay Back Period (DPBP) (Dacoure, 2016; Eshun, 2016).

The Net Present Value is defined as the sum of the present value or worth of all incomes minus the sum of the present value or worth of all after tax expenditures calculated at the minimum rate of return (i). It may be expressed mathematically as in Equation (1)

$\mathrm{NPV}=\sum \mathrm{PV}$ of cash inflow @ i $-\sum \mathrm{PV}$ of cash outflows@i
If a projects NPV is positive (NPV $>0$ ), the project is considered to be economically acceptable. When the NPV is zero $(\mathrm{NPV}=0)$, the project breaks even. When the NPV is negative $(\mathrm{NPV}<0)$, the project is considered to be economically unacceptable (Dacoure, 2016).

The NPV criterion has the following characteristics which makes it suitable as an evaluation criterion:

1) It takes into account the time value of money by specifying the interest rate in the calculation;

2) It provides a single number of cash equivalent, which can be used as an index for comparison at a specific point in time $(\mathrm{t}=0)$; and

3) The NPV value is always a unique quantity for a given interest rate.

Internal Rate of Return is defined as the interest rate at which the NPV of a project is equal to zero. Mathematically, this may be expressed as follows in Equations (2) and (3):

IRR = $\mathrm{i}$ for $\sum \mathrm{PV}$ of cash inflow $@ \mathrm{i}=\sum \mathrm{PV}$ of cash outflows@i

IRR=I for NPV@I=0

If a projects IRR is greater than the minimum rate of return $($ IRR $>\mathrm{i}$ ), the project is considered to be economically acceptable. When the IRR is equal to the minimum rate of return $(I R R=i)$, the project breaks even. When the IRR is greater than the minimum rate of return (IRR $<\mathrm{i}$ ), the project is considered to be economically unacceptable.

Discounted Pay Back Period (DPBP) is defined as the time (number of years) required for the net cash flow from a project to pay back the initial investment taking into consideration the time value of money.

If the DPBP is less than some minimum value acceptable to the company, the project is considered to be acceptable. The shorter the DPBP, the more acceptable the project becomes.

According to (Gentry and O'Neil, 1984), the cash flow of any business may be defined as the difference between the total cash receipts (inflows) and the total cash disbursements (outflows) for a given period of time, typically one year. Mathematically, this can be expressed as in Equation (4):

$$
\text { Cash Flow }=\sum \text { cash inflows }-\sum \text { cash outflows }
$$

The annual gross revenue from a satisfactory mining project must normally be sufficient to pay operating 
costs and other deferred tax deductions such as loss carry forward deductions before paying income tax with the resulting after tax revenue being the company's net profit for the year. Normally, only the operating cost, interest on loan and various income tax expenditures are the actual corporate disbursements during the year.

Sensitivity analysis of a mineral project refers to the investigation of the effect of changes in the project's economic parameters on the economic viability of the project. Sensitivity analysis is a way to predict the outcome of a decision if a situation turns out to be different compared to the key prediction(s). It is required because the project's economic parameters such as the capital cost, operating cost and revenue, used in the economic evaluation of the project are only estimates (Gentry and O’Neil, 1984). Now, every estimated value has some degree of error associated with it and therefore may not be the real value. Again, by the time a mining project is being commissioned, all estimated values of the economic parameters may have changed, therefore the need to determine the magnitude of change in the economic parameters that the project can absorb and remain attractive to investors (Tchikaya, 2016). There are three ways by which sensitivity analysis can be done, namely the single variable sensitivity analysis; the range approach to sensitivity analysis and the probabilistic sensitivity analysis. Of these, the single variable sensitivity analysis is mostly used in the economic evaluation of mineral projects. The study considered two fiscal policy regimes: the 2003 Mining Code issued on the 8th of May 2003 and the new 2015 Mining Code signed by the President of Burkina Faso on the 16th July, 2015. The prominent fiscal policies within the two regimes that are applicable to the economic evaluation of the mineral projects in Burkina Faso are summarised in Table1.

Table 1: Summary of the main Fiscal Parameters used in the Economic Evaluation of Mineral Projects under the two Fiscal Policy

\begin{tabular}{|c|c|c|}
\hline \multicolumn{3}{|c|}{ Regimes. } \\
\hline & 2003 Mining Code & 2015 Mining Code (New) \\
\hline $\begin{array}{l}\text { Royalty } \\
\text { (Ad Valorem) }\end{array}$ & $\begin{array}{l}3 \% \text { when ounce of gold price is less than } 1000 \$ \\
4 \% \text { when it is between } 1000 \$-1300 \$ 5 \% \text { when } \\
\text { above } 1300 \$\end{array}$ & $\begin{array}{l}3 \% \text { when ounce of gold price is less than } 1000 \$ \\
4 \% \text { when it is between } 1000 \$-1300 \$ 5 \% \text { when } \\
\text { above } 1300 \$\end{array}$ \\
\hline Surface fees & $\begin{array}{l}\text { From US } \$ 5 \text { to US } \$ 40,000 \text { per square kilometers per } \\
\text { year depending on the } \\
\text { type of metals }\end{array}$ & $\begin{array}{l}\text { From US } \$ 5 \text { to US } \$ 40,000 \text { per square kilometers } \\
\text { per year depending on the } \\
\text { type of metals }\end{array}$ \\
\hline $\begin{array}{l}\text { Local } \\
\text { Community } \\
\text { Development Fund }\end{array}$ & ---- & $1 \%$ of monthly turnover \\
\hline Corporate Income Tax & $17.50 \%$ & $27.50 \%$ \\
\hline Tax on dividends & $6.25 \%$ & $12.50 \%$ \\
\hline Value Added Tax & $18 \%$ & $18 \%$ \\
\hline State Participation & $10 \%$ free equity & $10 \%+$ possible additional equity \\
\hline Capital Allowance & Accelerated (declining balance method) & Accelerated (declining balance method) \\
\hline
\end{tabular}

Basic Assumptions and Principles: The project cost estimation was done to make available realistic cost values that served as a stepping stone for the evaluation of the economic potential of the Natougou project.

The following assumptions and principles were used for the estimation process: (i) Contingency allowance of $15 \%$ was assumed to take care of all unforeseen cost elements within the defined scope of the project; (ii) No allowances were made to cater for escalation in the estimates; (iii) The yearly production of $1340000 \mathrm{t}$ was assumed to be constant each year; (iv) The surface tax for this particular project averaged 13500 $\$ / \mathrm{km}^{2} / \mathrm{yr}$; (v) The $1 \%$ of the monthly turnover estimated to be paid to the Local Community Development; (vi) Fund by mining companies was assumed to be paid every year at the same flat rate of
1\%; (vii) The gold price used in the analysis will be the same each year leading to the same annual gross revenue; and (viii). The Marginal Weighted Average Cost of Capital is estimated to be $20 \%$.

Please note that all cost estimates were made in US dollars as the local cost components were changed from CFA Francs to US dollars with an exchange rate of US\$ 1 being equivalent to $614.8 \mathrm{CFA}$.

Please note that all cost estimates were made in US dollars as the local cost components were changed from CFA Francs to US dollars with an exchange rate of US\$ 1 being equivalent to $614.8 \mathrm{CFA}$.

Capital Cost Estimates: In order to make a very sound investment decision, current equipment prices and construction cost of facilities were obtained from manufacturers, contractors and through comparison with existing mines. Burkina Faso being a landlocked 
country, an additional $15 \%$ of purchase cost was added to the purchase cost of all equipment that would be purchased outside Burkina Faso to take care of shipping and any other unforeseen cost. The capital costs were grouped under four categories. The estimated total capital cost in US Dollars (US\$) was 219600000.00

Estimation of Operating Cost: Some assumptions were made when estimating the operating cost of the project. The assumptions include: (i) Both skilled and unskilled labour will be sourced from Burkina Faso and where training is required, the company will ensure that it is given to suitable candidates; and (ii) The use of expatriates will be limited to top management staff.

The operating cost of the Natougou project was based on a working regime of 12 hours per shift, 2 shifts per day and 335 working days per year leading to an annual production of $1340000 \mathrm{t}$ of ore. Considering an average stripping ratio of 7.1, it means that 18224 $000 \mathrm{t}$ of waste would be mined annually and sent to the waste dumps. The mine will employ drilling and blasting as the main methods though some amount of ripping will be done. The operating costs have been categorised into mining, processing and overheads. Table 2 presents a detailed operating cost of the project.

Table 2: Estimates of Average Operating Costs Obtained from Vendors

\begin{tabular}{ll}
\hline Cost Centre & Estimate (US\$) \\
\hline Pre-Production Costs & \\
Acquisition, Exploration and Consultation & 8228841.50 \\
Subtotal & 8228841.50 \\
Direct Capital Cost & \\
Mining (Ore and Waste) & \\
CAT D10T Dozer $\times 5 ;$ & 4161316.12 \\
CAT 14G Grader $\times 4$; & 2301851.61 \\
CAT 988F FEL $\times 4 ;$ & 2813374.19 \\
Leibherr 984 Excavator $\times 8 ;$ & 7661249.51 \\
CAT 777D Dump Truck $\times 30 ;$ & 37145983.82 \\
Drill Machine $\times 8 ;$ & 9207406.44 \\
Explosive Truck $\times 1 ;$ & 230185.16 \\
Water Truck $\times 1$; and & 962448.38 \\
Mine Vehicle $\times 35$ & 3516717.74 \\
Haul Roads & 2557612.90 \\
Engineering $(10 \%)$ & 7055814.59 \\
Subtotal & 77613960.47 \\
Processing Plant Services & \\
Carbon In Leach Tank $\times 4$ & 5502319.58 \\
Stripping and Electro wining & 81176.41 \\
Carbon Regeneration Kiln & 51152.26 \\
Smelting Furnace & 54348141.86 \\
Tailings Dam & 3341481.29 \\
Engineering $(10 \%)$ & 6332427.14 \\
\hline
\end{tabular}

Estimation of Project Revenue: In estimating the annual revenue of the project a gold price of
US\$1100.00/oz (US\$ 35.3658/g) was used. The annual mine revenue is estimated using Equation (5)

$R=(T)[1+D-L](G)(r)(P)$

where; $\mathrm{T}$, tonnage of ore produced per year $(\mathrm{t} / \mathrm{yr})=$. $340000 \mathrm{t} / \mathrm{yr} ; \mathrm{G}$, mill head grade $(\mathrm{g} / \mathrm{t})=3.32 \mathrm{~g} / \mathrm{t}$; R, mill recovery $=0.929 ; \mathrm{L}$, ore loss $=0.05 ; \mathrm{D}$, ore dilution $=0.20 ; \mathrm{P}$, unit price of gold $(\mathrm{US} \$ \mathrm{~g}) ;=\mathrm{US} \$$ 1,100.00/oz. (US\$ 35.36/g); R = $1340000(1+0.20-$ 0.05) (3.32) (0.929) (35.36); R= US \$ 168061676.97

\section{RESULTS AND DISCUSSIONS}

Evaluation of the Economic Viability of the Natougou Project under two Fiscal Policy Regimes:

The following estimates and basic assumptions were used in the economic evaluation of the Natougou Project: (i) Total capital investment $=\$ 219600000$ (ii) Annual operating cost $=\$ 59938200 / \mathrm{yr}$. (iii) Annual production $=340000 \mathrm{t} / \mathrm{yr}$. (iv) Gold price $=\$$ $35.36 / \mathrm{g}$ (v) Mill head grade $=3.32 \mathrm{~g} / \mathrm{t}$ ( vi) Recovery $=0.93$ (vii) Ore dilution $=20 \%$ (viii) Ore loss $=5 \%$ (viii) Project life $=08$ yrs. (ix) Interest on loan capital $=15 \%(\mathrm{x})$ Discount rate $=20 \%$ (xi) Capital structure $=50 \%$ equity and $50 \%$ loan (xii) Working capital $=$ $25 \%$ of annual operating cost

Economic Evaluation of the Natougou Project under the 2003 Mining Code: Table 3 shows the result of the cash flow analysis of the Natougou Project under the 2003 Mining Code. Since the NPV of US \$ 93817 833.84 is greater than zero and the IRR of $44.67 \%$ is greater than the minimum rate of return of $20 \%$, the Natougou Project is declared to be economically viable under the 2003 Mining Fiscal Policy Regime.

Table 3: Cash Flow Analysis under the 2003 Mining Code

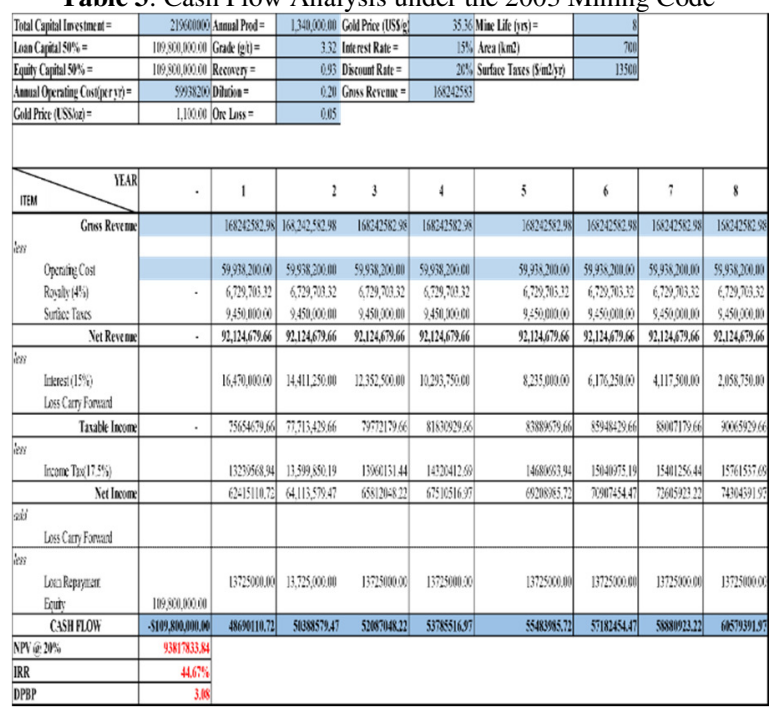


Fig. 2 and Fig. 3 present the sensitivity analysis of the Natougou Project under the 2003 Mining Code which has been conducted by varying the capital cost, operating cost and revenue within a range of $\pm 40 \%$. The result of the analysis clearly demonstrates that the Natougou Project is not sensitive to the variation of capital cost and that of operating cost within the range of $\pm 40 \%$.

However, when the revenue decreases beyond $18.35 \%$, the Natougou project will no longer be economically viable.

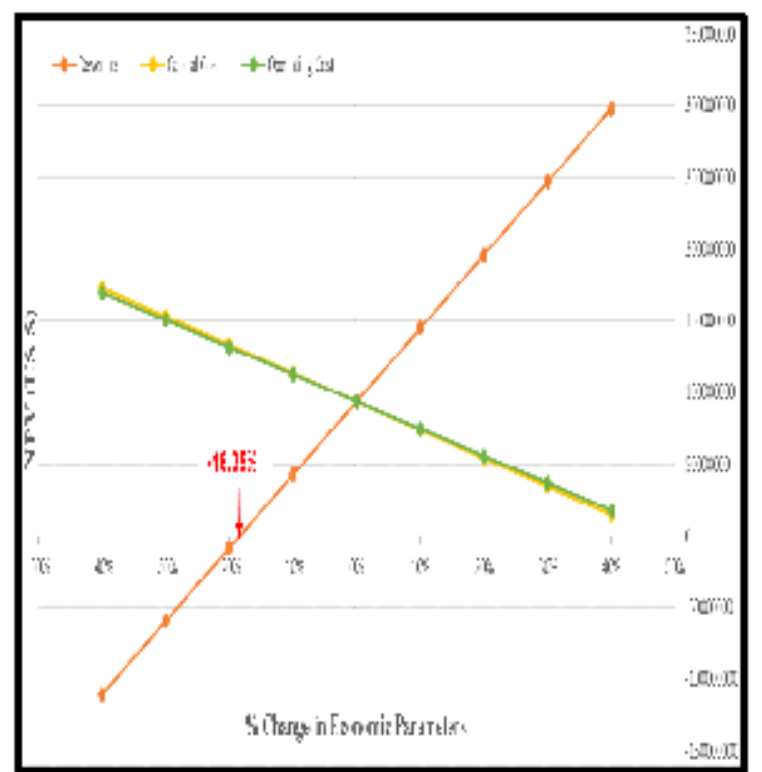

Fig. 2: NPV vs. Variation of Revenue, Capital Cost and Operating Cost (2003 Code)

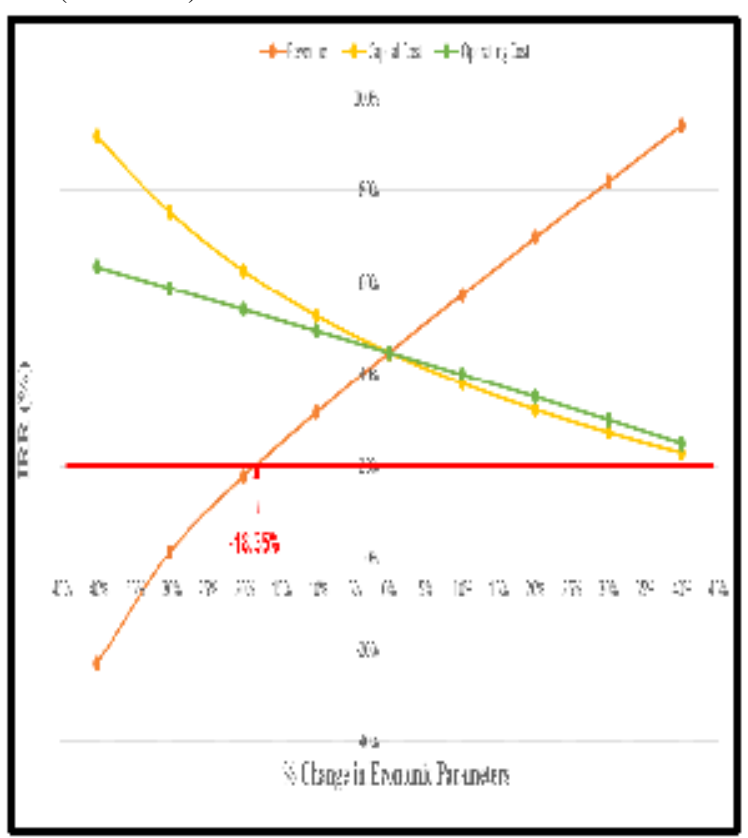

Fig. 3 IRR vs. Variation of Revenue, Capital Cost and Operating Cost (2003 Code)

Economic Evaluation of the Natougou Project under the New 2015 Mining Code: Table 4 presents the result of the cash flow analysis of the Natougou Project under the New 2015 Mining Code. Since the NPV of US \$ 58072836.55 is greater than zero and the IRR of $35.72 \%$ is greater than the minimum rate of return of $20 \%$, the Natougou Project is declared to be economically viable under the 2015 Mining Fiscal Policy Regime. Fig. 4 and Fig. 5 present the sensitivity analysis under the New Mining Code conducted by varying the revenue, operating cost and capital cost within a range of $\pm 40 \%$. The result indicates that the Natougou Project is sensitive to all the economic parameters taken into consideration. In fact, the Natougou Project will cease to be viable if the revenue decreases beyond $13.04 \%$ or if both operating cost and capital cost increase beyond $32.75 \%$ and $30 \%$ respectively with the variation of $\pm 40 \%$.

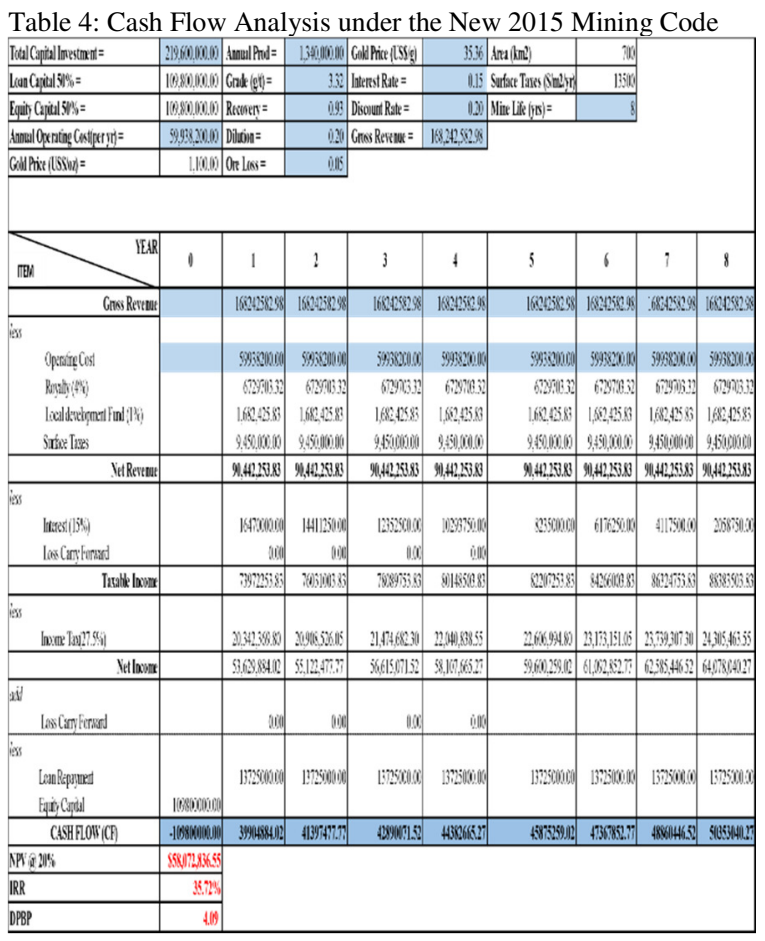

Comparative Analysis: (Laportes and Quatrebarbes, 2015; Laporte et al., 2017) highlight the heterogeneity of mineral fiscal policies in Africa and gives insights about the impacts on investment. Fig. 3 and Fig. 4 show the results of the cash flow analysis of the Natougou Project under the policy regimes under consideration. It can be observed that the Natougou Project is more attractive under the 2003 Mining Code as the obtained NPV and IRR from the cash flow under 
the 2003 regime were respectively greater than the NPV and IRR obtained under the 2015 regime.

Moreover, the percentage fall in NPV is $38.10 \%$ and represents an amount of US $\$ 35744997.29$ while the percentage fall in IRR is of $8.95 \%$.

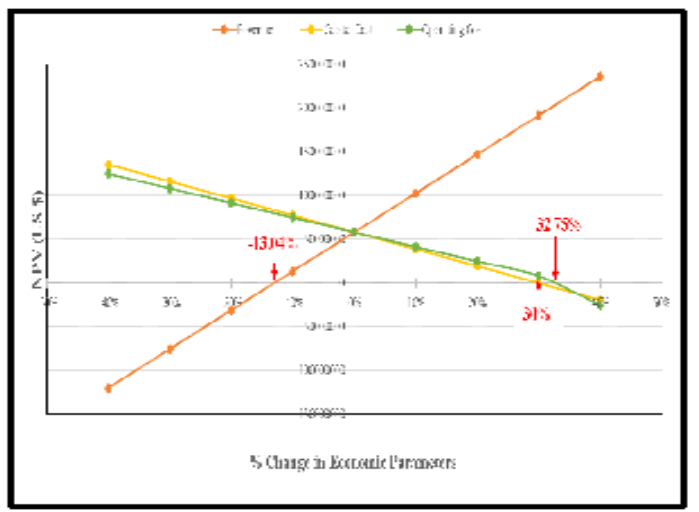

Fig. 4: NPV vs. Variation of Revenue, Capital Cost and Operating Cost (2015 Code)

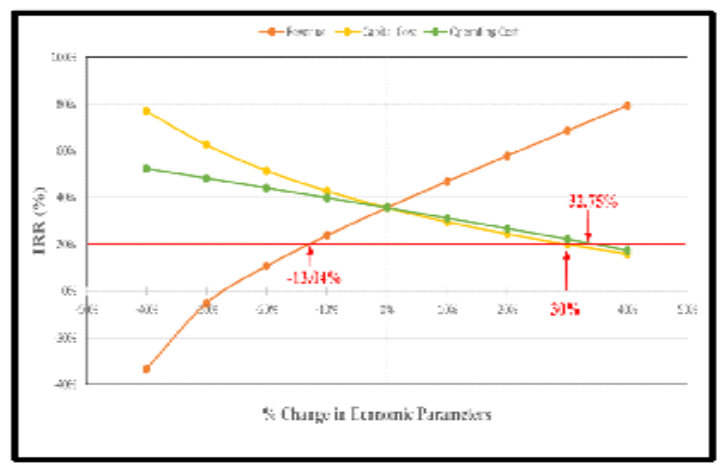

Fig. 5: IRR vs. Variation of Revenue, Capital Cost and Operating Cost (2015 Code)

Conclusion: The paper demonstrates the effectiveness of the Burkina Faso's Revised Mine Code of 2015 and the applicability of the 2013 Mining Code. It demonstrates the extent to which the country can potentially mobilise internal revenue as well as promoting a feasible national and international value chains.

\section{REFERENCES}

Anon (2009). Burkina Faso Code minier Loi $\mathrm{n}^{\circ} 031$ 2003/AN du 8 mai 2003 Modifié par la L.F.2009.29p http://www.droit-afrique.com/upload/doc/

burkina/Burkina-Code-minier-2009.pdf [Accessed 14 May,2018]

Anon. (2015). Loi No. 036-2015/CNT Portant Code Minier Du Burkina Faso. Jo No.44 du 29 Octobre 2015 52p

Barra, K. G (2015). Economic Evaluation of Mineral Projects- A Case Stud, Unpublished BSc. Project
Report, University of Mines and Technology, Tarkwa, Ghana,35 pp.

Calame, M (2015). Burkina Faso Mining and Metals Tax Guide', [online] http://www.ey.com/publication/vwluassets/ey-miningtax-alert-burkina-faso-august-2015/\$file/ey-miningtax-alert-burkina-faso-august-2015.pdf [Accessed March 05, 2017].

Dabire, P. T (2015). New Mining Code to Unlock Gold Revenues for the Future of Burkina Faso, [online] ht tp://www.publishwhatyoupay.org/new-mining-codeto-unlock-gold-revenues-for-the-future-of-burkinafaso/; [Accessed February 23, 2017].

Doucoure, A (2016). Assessment of the Economic Viability of an Open Pit Mine- A Case Study, Unpublished BSc. Project Report, University of Mines and Technology, Tarkwa, Ghana:30p.

Eshun, P. A.(2016). Mineral Project Evaluation, Unpublished BSc Lecture Notes, University of Mines and Technology, Tarkwa, Ghana: 30p.

Gentry, D.W and O'Neil.T.J. (1984) Mines Investment Analysis, Society of Mining Engineers, New York; 1984:396.

Laporte B., De Quatrebarbes C., Bouterige Y (2017). Mining Taxation in Africa: Gold Industry in 14 Countries from 1980 to 2015."Études et Documents, $n^{\circ}$ 13 , CERDI http://cerdi.org/production/show/id/1882/type production_id/1, 2017 [Accessed January 15, 2017]

Laporte, B and C. De Quatrebarbes, (2015). What Do You Know About Mineral Resource Rent Sharing in Africa? Resources Policy. 46: 234-249.

Smith, J (2013) Issues in Extractive Resource Taxation: A Review of Research Methods and Models, Resources Policy 34, p320-331. p. 320-331.

Tchikaya, A. C (2016). Comparative Analysis of the Economic Attractiveness of the Mineral Policy Reforms in Gabon- A Case Study Approach, Unpublished BSc. Project Report, University of Mines and Technology, Tarkwa, Ghana.

Tilton, J (2004). Determining the Optimal Tax on Mining, Natural Resources Forum, 28, pp. 144-149.

Wafwana, E. M (2013). Overview on Mining Law in Burkina Faso and Current Trends, [online] https://www.lexology.com/library/detail.aspx?g=0485 2a36-32a4-40e4-8188-e6a78e97495e, [Accessed February 23, 2017]. 